\title{
IMPLEMENTING WASTEWATER TREATMENT PROJECTS THROUGH BUILD-OPERATE-TRANSFER CONTRACTS
}

\author{
A.C. KARMPERIS , A. SOTIRCHOS , K. ARAVOSSIS \& I.P. TATSIOPOULOS \\ Sector of Industrial Management and Operational Research, \\ School of Mechanical Engineering, \\ National Technical University of Athens, Greece.
}

\begin{abstract}
This paper focuses on the initial assessment of wastewater treatment (WT) projects through Public Private Partnerships (PPPs). Due to the fact that the initial investment of a PPP-type WT project is too high and can be financed by both the public and private sectors, crucial during the project's feasibility stage is to estimate the partners' funding rates. Herein, the financial analysis that is included in the cost benefit analysis methodology as well as the quantitative value for money assessment method are used, in order to introduce a new process that estimates the funding ratios of the partners. Specifically, the process calculates the upper and lower boundaries of the public and private sectors' funding ratios in the initial investment, which include all the funding scenarios that are profitable for both partners. It applies mostly in the WT projects that are considered to be implemented through the build-operate-transfer contract type, which is probably the most commonly used type in PPPs. The new process is used in a WT project case study, in which alternative funding scenarios of the initial investment are examined and two specific funding scenarios are distinguished, which include all the possible funding ratio values by the public and the private parts. The process that is presented here can be a useful tool to decision makers, because it helps them to evaluate different funding scenarios of the initial investment and to select the most suitable in each case option, that will be profitable for both partners.
\end{abstract}

Keywords: cost benefit analysis, funding scenarios, Public Private Partnerships, value for money, wastewater treatment projects

\section{INTRODUCTION}

Nowadays, there is a growing trend for governments in the construction industry to place major projects into the private sector through the Public Private Partnerships (PPPs) [1, 2]. In the literature, there is no common definition of PPPs [3] and the definitions given by many scholars present some differences [4-8]. However, a common point among different approaches is that PPP contracts are long-term agreements for cooperation between public and private sector to provide high quality infrastructure, products or services, delivered via a process of applied risk-sharing, resources and profits. Generally, it is mentioned that the operational phase of a PPP project is 10-30 years [9-11], while these contract types have many advantages as well as some limitations [12]. For the period 1990-2007, the World Bank Group's [13] database that includes data from 134 countries and 4,300 infrastructure projects with private participation, show that the peak of investment projects in the water and sewerage sector was in the year 1997. In 2007, the investments in the specific sector amounted to US $\$ 3$ billion, within the US $\$ 2-3$ billion range of the three previous years. However, a remarkable issue is the period 1985-2004 in the USA [14]. Particularly, even though the wastewater projects were $41 \%$ and the road projects $20 \%$ of the total PPP projects, the investments in the wastewater sector cost much lower, that is US $\$ 82$ billion against US $\$ 577$ billion for the relative investments in the road sector. In Central-East Asia, where it is estimated that the number of poor people is higher than 720 million, approximately $60 \%$ of the world's poor, large water projects were implemented through PPPs [15]. Specifically, wastewater treatment (WT) projects have been implemented in Shanghai and Chengdu, China, in Ahmedabad and Chennai, India, in Surabaya, Indonesia, in Bangkok, Thailand, in Ho Chi Minh, Vietnam, [16, 17], mainly following the build-operate-transfer (BOT) type, which is the most used type in PPP contracts [18]. Moreover, BOT contracts have been 
followed for the implementation of WT projects in Izmit, Turkey, in Chihuahua, Mexico, in Johor, Malaysia, while a build-own-operate contract has been used in Sydney, Australia and full privatization contracts in England and Wales [19]. In the European Union (EU), PPP markets are continuously growing according to each country's model. Indicatively, EU member states can be separated in three stages, according to each country's experience in PPPs: the UK, Germany, Ireland and Italy in the most advanced stage, Spain and Portugal in the middle and the other countries in the initial stage [23]. This fact led the European Commission (EC) to publish the guidelines for PPPs [20], as well as the Green Book on PPPs [21], which is a book of 22 questions, in order to collect data from member states and establish a common legislative framework [22] in the future. However, due to fiscal limitations that the global economic crisis of 2008 induces, it is expected that these contract types will continue to play an important role in public procurement in the future.

\section{EVALUATION OF BUILD-OPERATE-TRANSFER PROJECTS}

\subsection{Public sector comparator}

In the literature, there are several methods proposed for the financial evaluation of PPP projects, such as the cost benefit analysis (CBA) [24], the NPV-at-risk method [25] and the public sector comparator (PSC) [26]. (CBA is a technique designed to determine the feasibility of a project or plan by quantifying its costs and benefits.) (PSC is a decision-making process, which evaluates whether a private investment proposal offers value for money (VfM) in comparison with the most efficient form of public procurement.) However, it is recommended that all public procurements of goods and services should be based on the best VfM, which can be defined as the optimum combination of whole-life costs and benefits to meet the project's objectives [27]. (VfM can be also seen as the optimum combination of whole life cost and quality, in order to meet the requirements.) Furthermore, the evaluation approaches that are mainly used is the full CBA of the public and private options, the PSC before bids invited and the UK style of VfM assessment [28]. Specifically, in the UK as well as in Australia, the qualitative and quantitative processes which are used to determine the VfM, take into consideration all the costs and benefits included in a project's lifecycle [29-31]. Additionally, the private finance initiative (PFI) projects, incorporated in PPP programs, have been developed in the UK. The PFI projects first appeared in 1992 and have been extremely increased by 2 in 1994, 11 in 1995, 39 in 1996, almost 500 in 2002 [32] and approximately 668 by the end of 2010 [33]. These contract types are based in public services provision, operated and also financed by the private sector $[34,35]$. Currently, the existing UK guide for the VfM assessment [36] presents the methodology of approaching and estimating the VfM that results by the comparison of the PFI against the conventional procurement $(\mathrm{CP})$ option. This comparison is implemented by preparing a hypothetical set of costs for the public procurement delivering the same output, in order to highlight the financial differences between the two procurement options. The overall approach is divided in three stages, while for the first two stages is necessary to implement both the qualitative and the quantitative assessment. Indicatively, the quantitative assessment is accomplished with a spreadsheet use, by following the instructions of the corresponding guide [37]. However, taking into consideration that the appropriate risk allocation is a critical success factor in PPP projects [38], it is crucial that the risks should be allocated to those parties that are best able to manage $[39,40]$.

\subsection{Cost benefit analysis}

On the other hand, the CBA methodology as presented in the CBA guide for investment projects, issued by the EC [41], includes six basic steps: the presentation and discussion of the socio-economic 
context and the project's objectives, the clear identification of the project, the study of the project's feasibility and the alternative options, the financial analysis, the economic analysis and the risk assessment. A remarkable issue is that the preparation and submission of a project proposal including a CBA, is mandatory for all large projects co-financed by the European Community for the 2007-2013 period, where large are considered the environmental projects whose budget are over $€ 25$ million and over $€ 50$ million for the other categories [42]. The main purpose of the financial analysis is to use the project cash flow forecasts, in order to calculate the financial indicators, namely the financial net present value (NPV) and the financial internal rate of return (IRR). (NPV is the difference between the present value of cash inflows and the present value of cash outflows that is used in capital budgeting to analyze the profitability of an investment or project. IRR is the discount rate used in capital budgeting that makes the NPV of all cash flows equal to zero.) Cash flows arising in different years of the project's lifecycle are calculated by the discount rate, following the discounted cash flow analysis, to adapt to the present value of future flows [43]. Especially in PPPs, it is recommended that financial analysis should include calculations of the $\operatorname{IRR}(\mathrm{g})$ and the $\operatorname{IRR}(\mathrm{p})$ indicators, respectively for the public ( $\mathrm{g}$ ) and the private $(\mathrm{p})$ investor, in order to show how the improved financial performance of the project is shared between the public and the private partner of the PPP. Moreover, economic analysis evaluates the contribution of the project to the economic welfare of the country and is implemented on behalf of the whole of society. The key concept is the use of accounting (shadow) prices, based on the social opportunity cost, instead of observed distorted prices, in order to calculate the economic net present value (ENPV) and the economic rate of return (ERR) indicators. Economic analysis' methodology is divided in five steps: conversion of market to accounting prices, monetization of non-market impacts, inclusion of additional indirect effects, discounting of the estimated costs and benefits and calculation of the economic performance indicators (ENPV, ERR and the benefit/cost (B/C) ratio). The last step of a CBA is the risk assessment, where the uncertainty about the forecasts that have already been calculated, is transformed into risk through the probability distributions of the examined indicators' values [44].

\subsection{Economic analysis of wastewater treatment projects}

Initially, we have to mention that the most effective way of reducing WT needs and costs, is to reduce the domestic water consumption through an effective water demand management [45]. Second step is the development of WT projects, which have to be planned according to the collection and treatment characteristics in each case. Generally, wastewater collection and treatment projects can be divided into municipal and industrial wastewater management projects and municipal are further divided into sewer construction and/or rehabilitation and treatment plant construction and/or rehabilitation [46].

Additionally, criteria for the selection of the appropriate system are based on factors such as the population density, the produced wastewater volume, the presence of shallow water wells susceptible to wastewater pollution, the soil permeability, the unit cost of wastewater collection and the socio-economic and cultural considerations. However, due to the fact that WT projects should be examined in a case-by-case basis, crucial is to distinguish the resulting benefits of the project. For instance, when dealing with the impact of wastewater, boundaries for downstream effects should be clear, either including the area affected immediately, or consider the impacts on irrigation, fishing and drinking water [47].

Moreover, due to the fact that typical environmental impacts are associated with the water quality as well as the soil and groundwater quality, the decrease or increase of the waters' quantity or quality produces some gains or losses in social benefits. Particularly, the actual related market price 
is used, in order to measure the economic value. On the other hand, if the market prices do not exist, there are relevant approaches that should be followed [48]. The most common approach is the use of the contingent valuation (CV) method by project analysts, which is a survey-based method frequently used for placing monetary values on goods and services not bought and sold in the marketplace. CV method has been used in many studies for the evaluation of a consumer's willingness to pay (WTP) for different product/services attribute [49]. Furthermore, in the appraisal of non-market goods, there is also the benefit transfer approach that is used for the environmental goods and services [50], while several other approaches are suggested in valuing time, health benefits, landscape or water [51].

\section{CASE STUDY: EVALUATION OF A WASTEWATER TREATMENT PROJECT}

The aim of this study is to examine an illustrative WT project in both the main evaluation methods, namely the VfM quantitative assessment and the CBA, in order to combine them suitably in a new process, which can be used for the evaluation of the partners' funding ratios, during the feasibility stage of the WT-type PPP projects. Furthermore, the results provided by the case study are discussed and the importance of the funding contribution ratios by the public and private sector during the conceptual project's phase is highlighted. Market prices, as well as conversion factors (CF) and the standard conversion factors (SCF) used in the specific case study, are equal to the values of the European CBA guides' relevant case study. Moreover, the estimated initial budget is divided equally in the two years of the implementation phase, while data used have rounded prices for the sake of simplicity. The project that is examined is an investment in the field of wastewater treatment, for the reuse of well-purified wastewater for multiple purposes after an intensive tertiary treatment process. It takes place in a member state of the EU and includes the construction of a new water purifier for a city of 200,000 residents in the initial year, while the population grows with an annual rate of $0.5 \%$. Currently, wastewater is discharged untreated into the river crossing the city and part of the water supply is obtained through wells, subjecting the groundwater to an over-abstraction. For this reason, the local aquifer has been depleted, and its hydro-geological level has been considerably lowered in recent years. During the feasibility stage of the project, public authorities have decided to examine the funding and procurement alternatives of the preferred option, which is the construction of the new water purifier, in order to decide about the sources of finance, that is only public financing, PFI option with no public financing or co-financed with EU's grant. It is assumed that the option analysis had already been executed, in which the business as usual as well as the do-minimum scenarios have been rejected, because both of them do not provide the desired results, that is the limitation of the river pollution and the protection of the local aquifer level.

\subsection{Assumptions - general}

The specific project includes a 2-year implementation and an 18-year operational of the WT system phases. Only financial inflows and outflows are considered, so value added tax, depreciation of fixed assets and other accounting tools are not counted. Moreover, the following assumptions have been taken into consideration:

\subsection{Initial investment, inflows and outflows}

The cost of the initial investment is estimated to be $€ 35$ million, with a $4.5 \%$ escalator rate. This is divided in $10 \%$ for the feasibility and technical studies, $5 \%$ in land expropriation, $25 \%$ in labor, $20 \%$ in materials for civil works, $10 \%$ in transports and rentals and $30 \%$ in electromechanical equipment. 
This cost is $10 \%$ higher under the PPP option, as more risk is transferred, that is $€ 31.5$ million through the CP option. The annual operational expenditures (employment) for the initial year of the operational phase are estimated to be $€ 630,000$ in present value: 25 unskilled personnel $(€ 25,200 /$ person per year), which follow a $3.5 \%$ escalator rate. On the other hand, the rest annual operational expenditures (non-employment) are estimated to be $€ 200,000$ and the lifecycle costs, which present the annual basis investments during the contract period to maintain the asset so that it remains fit for its intended purpose, are estimated to be $€ 450,000$ for the first year, which both follow a $2.5 \%$ escalator rate.These costs met by the private contractor as investments outflows, while inflows are the annual payments from the public sector. Taking into consideration that the daily water actual supply is estimated to be $190 \mathrm{l} / \mathrm{resident}$ which has a reduction factor of 0.8 due to water network leakages and that the purification charge will be $€ 0.32 / \mathrm{m}^{3}$, the expected revenues are: $200,000 \times 190 \times 365 \times$ $0.8 / 1000 \times 0.32=3,550,720 € / 1$ st year, which is altered by $2 \%$ annually $(1.5 \%$ inflation and $0.5 \%$ population growing demand).

\subsection{Discount rate}

According to $\$ 2.4$ of the EC's guide to CBA, the discount rate that is suggested by the EC, for the investment calculations in the Euro zone during the programming period $2007-2013$ is $5 \%$ for a long time. Notwithstanding, the above rate may vary depending on macroeconomic conditions in a member state, or depending on the type of investment, for example in PPP projects. For the present project, a $6.09 \%$ will be taken as the nominal discount rate, based on the Green Book real discount rate of $3.5 \%$ [51], and GPD (gross domestic product) deflator assumption of $2.5 \%$.

\subsection{Positive and negative externalities}

Critical factors that decision makers should take into account is the positive and negative external impact from the WT plant operation, that is the costs and benefits arising to users as well as the relative costs and benefits for the water resource itself and for the environment in general [51]. Due to the fact that the water supply services is a classic case of monopoly market, the revenues collected by the owner, even if corrected by means of appropriate CFs, do not represent the project's social benefits. Indicatively, some typical externalities for WT projects are presented as follows: the negative externality in the local area is the cost due to the noise, odors and esthetic and landscape impacts of the plant. The impact of noise was valued in $€ 26.4$ per decibel per household per year, with the inflation of $1.5 \%$ in the $€ 23.5$ price of 2001 [51]. However, for the sake of simplicity, the estimated hedonic price (see, e.g. [41, 52]), for the specific case study is 10,000,000/year, equal to the difference between the market value of the rent for the buildings in the area before the plant is built and the value after the plant is built. Further, the positive externalities arising from the specific project is the groundwater resource saving with the protection of the local hydro-geological level, as well as the generation of many positive environmental effects. Taking an accounting price of $€ 0.6 / \mathrm{m}^{3}$ of treated water, benefits are valued in $€ 6,657,600 /$ year. Additionally, with the use of an accounting price of $€ 0.7 / \mathrm{m}^{3}$ for the environmental protection of water and land and the safeguarding of human health and the integrity of human species, environmental benefits have an estimated value of $€ 7,767,200 /$ year.

\subsection{Quantitative VfM assessment}

In the case of the quantitative VfM assessment process, which includes the comparison of the CP against the PFI options, the positive and/or negative economic impact of the indirect VfM factors 


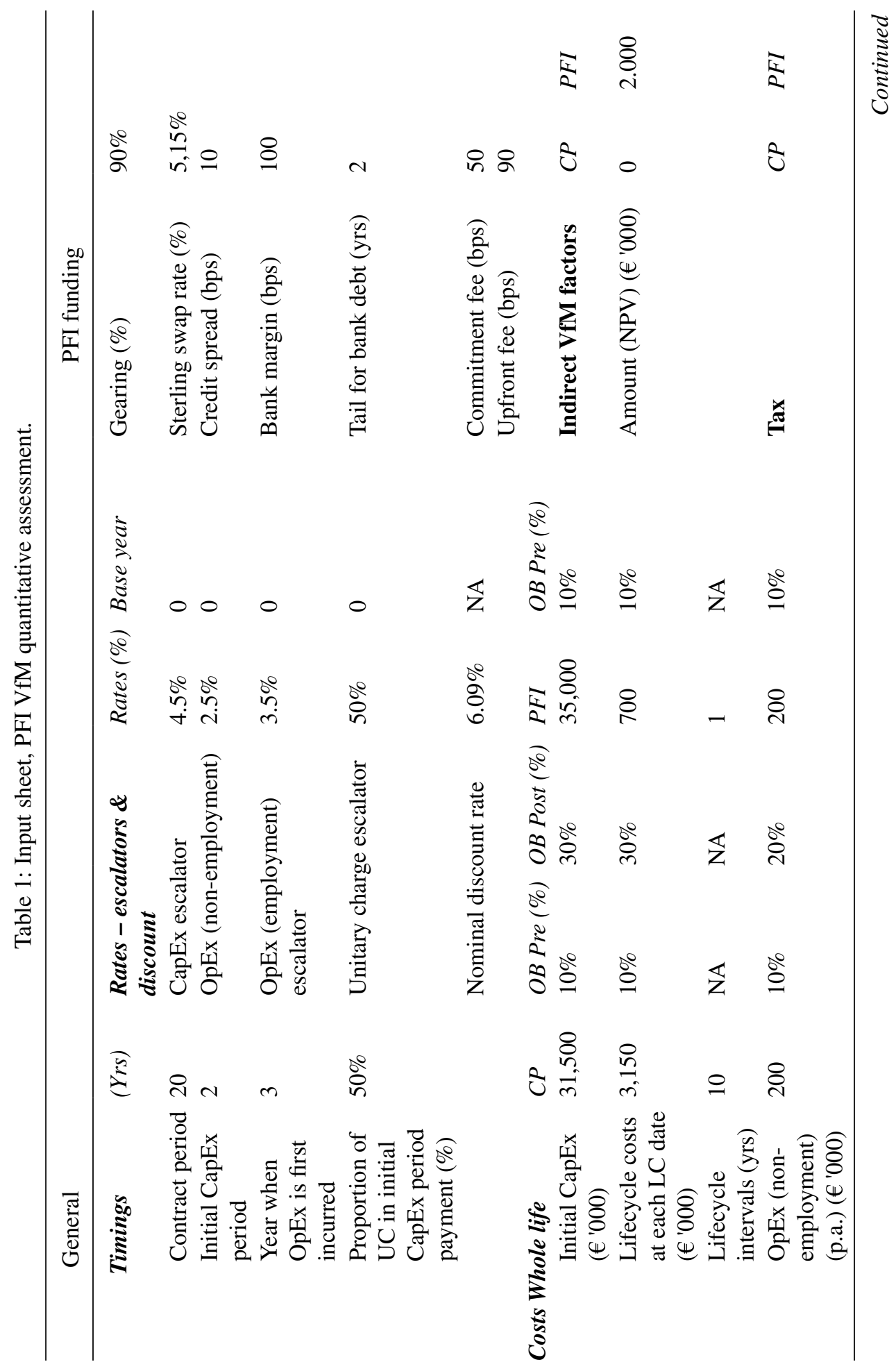




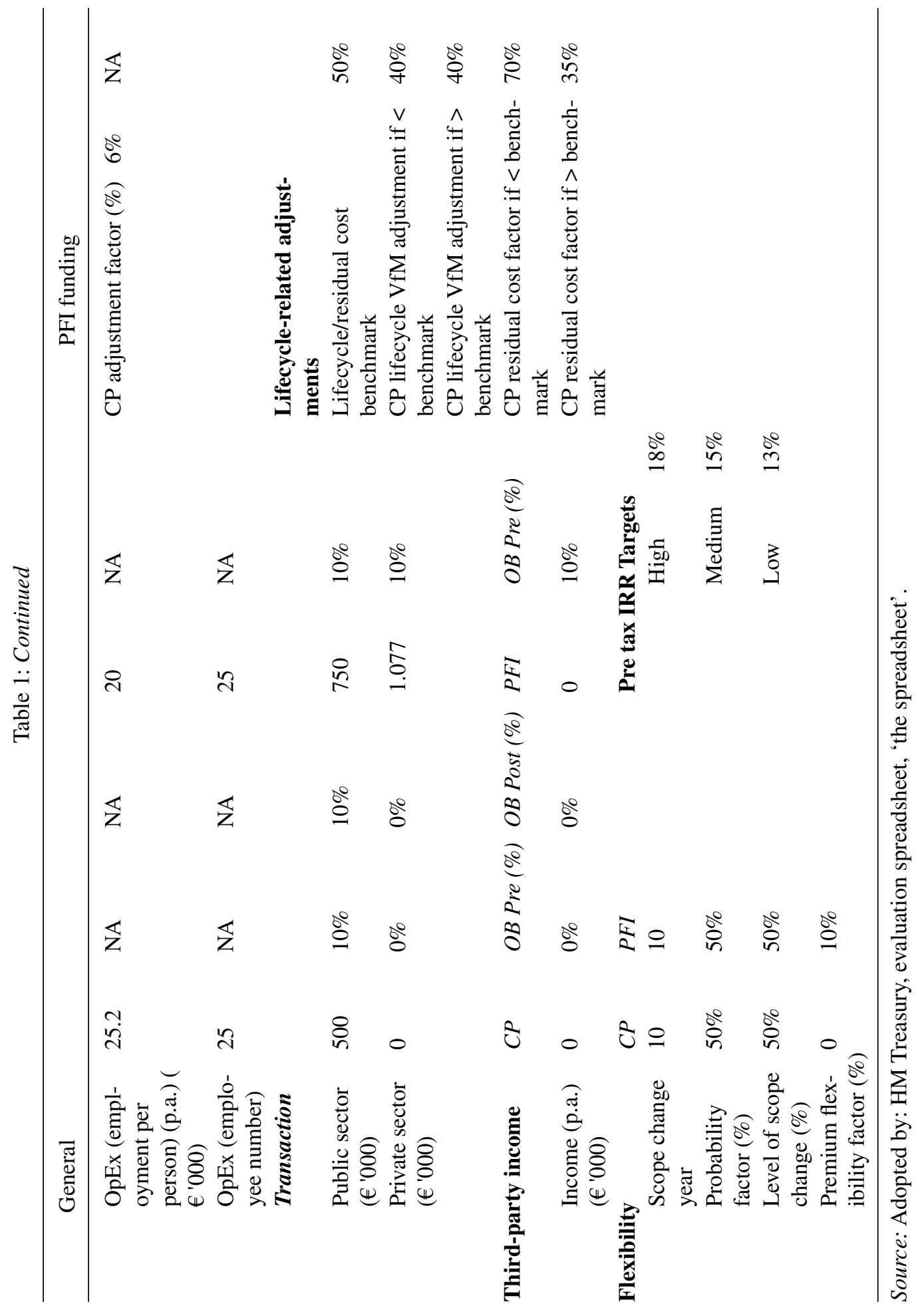


should be taken into account. However, only the factors that are likely to arise differentially under one of the tested options are calculated. In the present case study, it is assumed that the PFI option has a 2 million NPV against the PC option (due to risk allocation, design quality, etc.). Additionally, the lifecycle cost is taken into account for both options, which represent the cost that is invested during the lifecycle of the project, so the asset remains fit for its intended purpose. The 'input sheet' of the spreadsheet for the specific case study is illustrated in Table 1. Result of the spreadsheet for a pre tax target equity IRR of $18 \%$ is the 'indicative' VfM value of $17.45 \%$ in favor of the PFI option, that is the PFI is expected to have better VfM than the CP option. Furthermore, the point analysis shows that the switching value of capital expenditure factor is $-26 \%$, while the relative switching value of the unitary charge is $+28 \%$. These values lay outside the default benchmark tolerances of $-5 \%$ and $3 \%$, respectively.

However, this process does not take into account the revenues arising by the charging of users, since the payments to the private sector by the state through the unitary charge, are adjusted according to the pre tax equity IRR that is used each time. On the other hand, the revenues arising from an investment process as well as the co-financing rate by other organization are considered during the CBA execution process. A well-performed evaluation process with the combination of the above methodologies could help the decision makers to make the appropriate calculations and to estimate all the possible funding ratios for each of the public and private partners in the initial investment. The flowchart of the process that combines the above methodologies, in order to evaluate the alternative funding contribution ratios by the public and private parts, is illustrated in Fig. 1.

\subsection{Cost benefit analysis}

Through the quantitative VfM assessment process, it has already been demonstrated that the scenario of the project's implementation under the terms of PFI includes enough VfM. However, taking

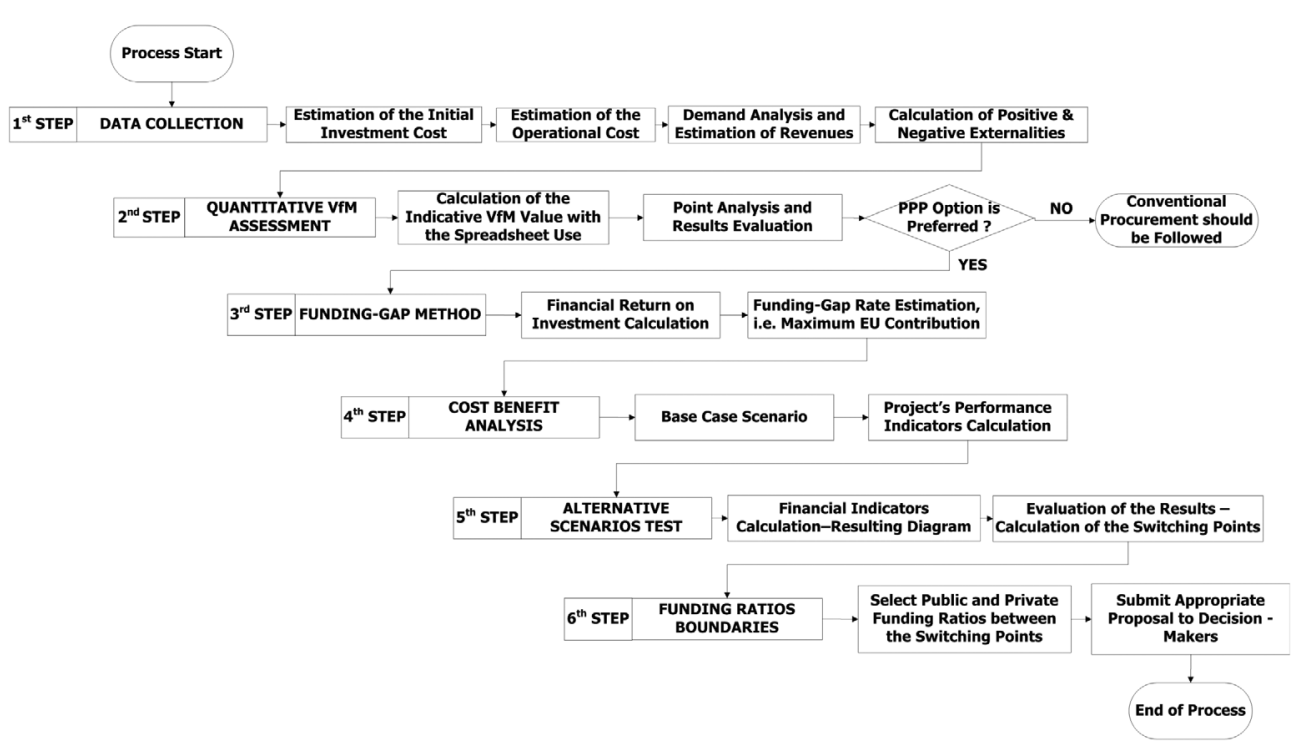

Figure 1: Wastewater treatment project through BOT contracts: process flowchart for the evaluation of the public and private funding contribution ratios in the initial investment. 
into consideration the revenues that the owner will have by the charging of users, it is recommended that project examiners should examine alternative funding scenarios, that is with different funding ratios in the initial investment, for the calculation of the investment indicators during the decisionmaking process. Due to the fact that the project will be implemented in an EU's member state, it is crucial to estimate the maximum amount to which the co-financing rate of the priority axis applies by following the funding gap method. Through this method, the funding gap rate is estimated and the funds that could possibly arise by the EU's contribution are estimated. The funding gap rate in the present case study is calculated in $22.72 \%$, that is the maximum EU contribution is $35 \times 10^{6} \times$ $0.2272=7.952 \times 10^{6} €$.

\subsection{A process for the estimation of the funding ratios}

The proposed process includes the initial calculation of investment's evaluation indicators under a base case scenario, taking into consideration the maximum EU funding, and further the analysis of these indicators under different funding ratios in the initial investment. The process flowchart is illustrated in Fig. 1 and presents a new algorithmic-type procedure, which can be used in the funding evaluation process of the WT projects implemented through PPPs.

\subsection{Base case and alternative scenarios}

EU contributes to the initial investment funding at $22.72 \%$ and the remaining $77.28 \%$ is covered equally, $38.64 \%$ for each of the public and private sectors. Indicatively, public funding includes an amount of $€ 6,762,000$ (19.32\% of investment costs) by equity, while the rest $19.32 \%$ is provided by a national or regional fund. Additionally, the private financing $(€ 13,524,000)$ is given by equity for $10 \%$ of the amount $(€ 1,352,400)$ and by loan for the other $90 \%(€ 12,171,600)$, which has a $6 \%$ interest rate with an amortization period of 10 years. The service fee paid to the private sector is set at $€ 0.256 / \mathrm{m}^{3}$ of treated water. Calculations of the returns on local public capital and private equity for the base case scenario are illustrated in Table 2. In these calculations, it has been taken for granted that the remaining of the initial investment that is not covered by the EU funding is divided equally (38.64-38.64\%) to public and private participants, as illustrated in Fig. 2. Next step is to analyze various levels of public and private participation, while maintaining full use of the EU funding.

\subsection{Calculations}

Calculations of the project's performance indicators under the alternative funding scenarios are also presented in Table 2, where it is shown that the economic indicators, namely the ENPV and the ERR get equal values for all the funding scenarios. Furthermore, the resulting diagram which is illustrated in Fig. 3, demonstrates that the four alternative scenarios results in negative financial indicators either for the public or for the private parts, that is $\mathrm{NPV}(\mathrm{g})<0$ and $\mathrm{NPV}(\mathrm{p})>0$, where $\operatorname{IRR}(\mathrm{g})<$ discount rate $<\operatorname{IRR}(\mathrm{p})$, or NPV $(\mathrm{g})>0$ and $\mathrm{NPV}(\mathrm{p})<0$, where $\operatorname{IRR}(\mathrm{p})<$ discount rate $<\operatorname{IRR}(\mathrm{g})$. Taking into consideration that the financial indicators of both participants should have positive values, crucial is the calculation of the switching points, which present the upper and lower boundaries of the public and private funding ratios, as presented in Fig. 3. Following the trial and error method, the evaluation process includes the calculation of the switching points' values. In the present case study, as can be seen in Fig. 4, the first switching point is calculated $28.45 \%$ for the private sector and $48.83 \%$ for the public sector $(24.42 \%$ by national or regional fund and $24.42 \%$ by local public capital) and the second switching point value is $51.80 \%$ for the private and $25.48 \%$ for the public 
Table 2: Calculations of the project's performance indicators according to different funding scenarios.

\begin{tabular}{|c|c|c|c|c|c|c|}
\hline & Scenarios & $1 \mathrm{st}$ & 2nd & Base case & 3 rd & 4th \\
\hline \multirow{5}{*}{ 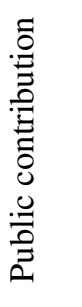 } & EU contribution & \multicolumn{5}{|c|}{$22.72 \%$ (equal for all the scenarios) } \\
\hline & $\begin{array}{l}\text { Local public } \\
\text { equity }\end{array}$ & $\begin{array}{l}€ 10,899,000 \\
(31.14 \%)\end{array}$ & $\begin{array}{l}€ 9,149,000 \\
(12.5 \%)\end{array}$ & $\begin{array}{l}€ 6,762,000 \\
(19.38 \%)\end{array}$ & $\begin{array}{l}€ 4,375,000 \\
(12.50 \%)\end{array}$ & $\begin{array}{l}€ 2,625,000 \\
(7.5 \%)\end{array}$ \\
\hline & National/ & $€ 10,899,000$ & $€ 9,149,000$ & $€ 6,762,000$ & $€ 4,375,000$ & $€ 2,625,000$ \\
\hline & Regional fund & $(31.14 \%)$ & $(12.5 \%)$ & $(19.39 \%)$ & $(12.50 \%)$ & $(7.5 \%)$ \\
\hline & Total & $\begin{array}{l}€ 21,798,000 \\
(62.28 \%)\end{array}$ & $\begin{array}{l}€ 18,298,000 \\
(52.28 \%)\end{array}$ & $\begin{array}{l}€ 13,524,000 \\
(38.64 \%)\end{array}$ & $\begin{array}{l}€ 8,750,000 \\
(25.00 \%)\end{array}$ & $\begin{array}{l}€ 5,250,000 \\
(15.0 \%)\end{array}$ \\
\hline \multirow{3}{*}{ 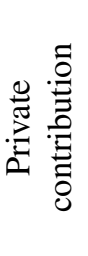 } & Equity & $\begin{array}{l}€ 525,000 \\
(1.5 \%)\end{array}$ & $\begin{array}{l}€ 875,000 \\
(2.5 \%)\end{array}$ & $\begin{array}{l}€ 1,352,400 \\
(3.86 \%)\end{array}$ & $\begin{array}{l}€ 1,829,800 \\
(5.23 \%)\end{array}$ & $\begin{array}{l}€ 2,179,800 \\
(6.23 \%)\end{array}$ \\
\hline & Loan & $\begin{array}{l}€ 4,725,000 \\
(13.5 \%)\end{array}$ & $\begin{array}{l}€ 7,875,000 \\
(22.5 \%)\end{array}$ & $\begin{array}{l}€ 12,171,600 \\
(34.78 \%)\end{array}$ & $\begin{array}{l}€ 16,428,200 \\
(47.05 \%)\end{array}$ & $\begin{array}{l}€ 19,618,200 \\
(56.05 \%)\end{array}$ \\
\hline & Total & $\begin{array}{l}€ 5,250,000 \\
(15.00 \%)\end{array}$ & $\begin{array}{l}€ 8,750,000 \\
(25.00 \%)\end{array}$ & $\begin{array}{l}€ 13,524,000 \\
(38.64 \%)\end{array}$ & $\begin{array}{l}€ 18,298,000 \\
(52.28 \%)\end{array}$ & $\begin{array}{l}€ 21,798,000 \\
(62.28 \%)\end{array}$ \\
\hline \multirow{6}{*}{ 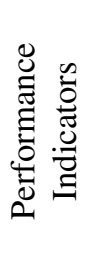 } & $\mathrm{NPV}(\mathrm{g})$ & $-2,155,490$ & $-553,300$ & $+1,632,100$ & $+3,817,500$ & $+5,419,700$ \\
\hline & $\operatorname{IRR}(\mathrm{g})$ & $+3.35 \%$ & $+5.29 \%$ & $+9.0 \%$ & $+15.4 \%$ & $+25.4 \%$ \\
\hline & $\mathrm{NPV}(\mathrm{p})$ & $+11,438,860$ & $+8,330,740$ & $+4,091,250$ & $-148,230$ & $-3,256,350$ \\
\hline & $\operatorname{IRR}(p)$ & $+105.73 \%$ & $+43.6 \%$ & $+15.5 \%$ & $+5.8 \%$ & $+1.7 \%$ \\
\hline & ENPV & \multicolumn{5}{|c|}{$+16,275,000$ (equal for all scenarios) } \\
\hline & ERR & \multicolumn{5}{|c|}{$+12.11 \%$ (equal for all scenarios) } \\
\hline
\end{tabular}

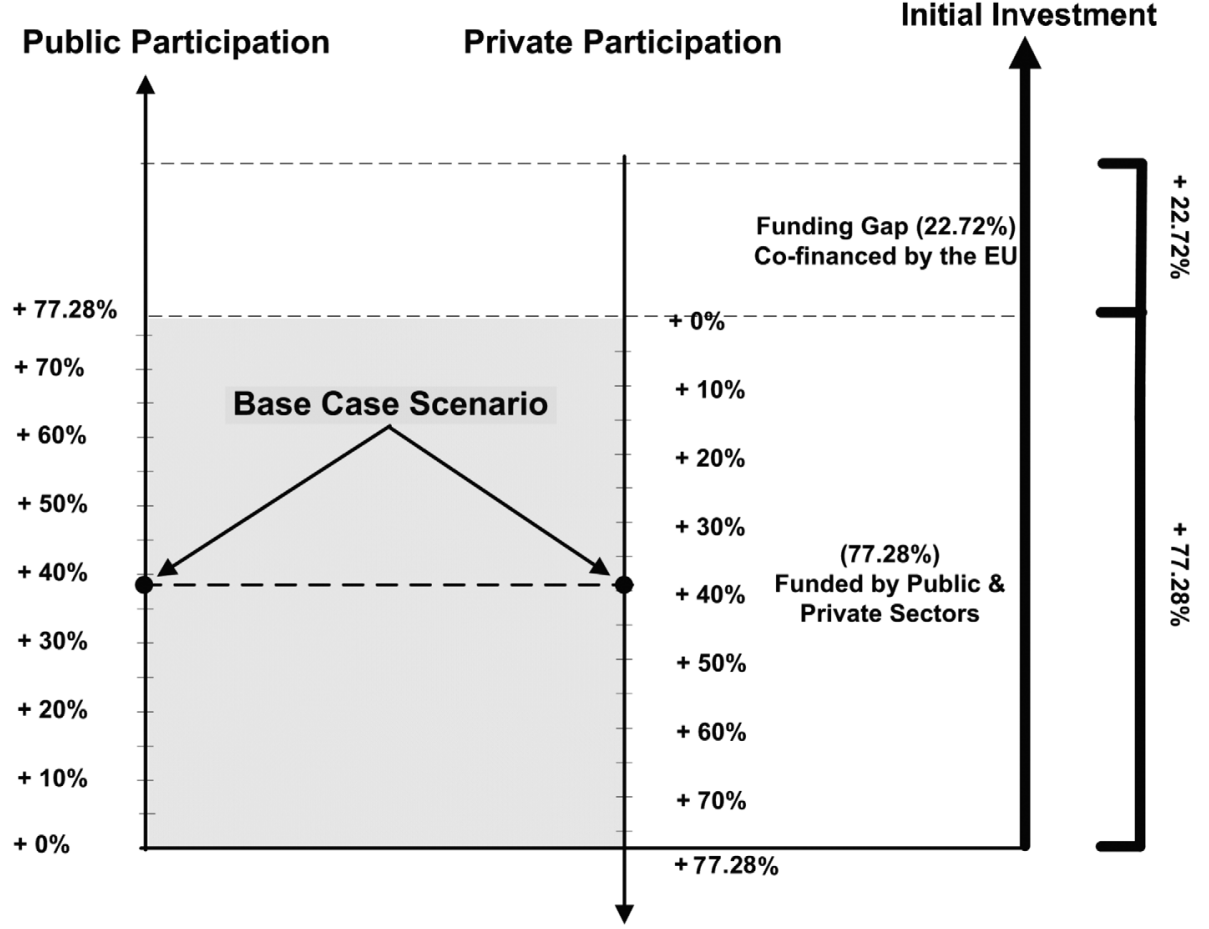

Figure 2: Base case scenario: equal funding of the initial investment by the public and private parts. 


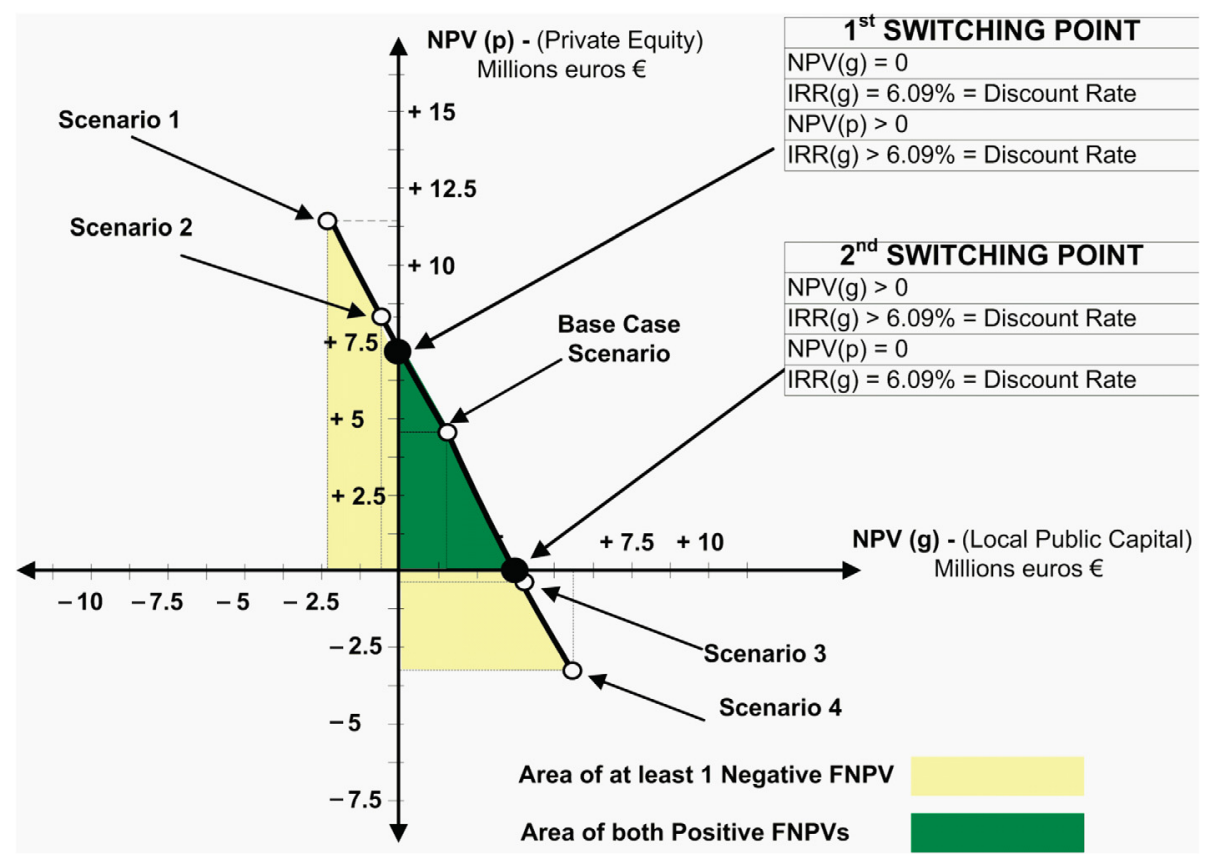

Figure 3: Evaluation of the alternative funding scenarios by the public and private partners in the initial investment - calculation of the switching points.

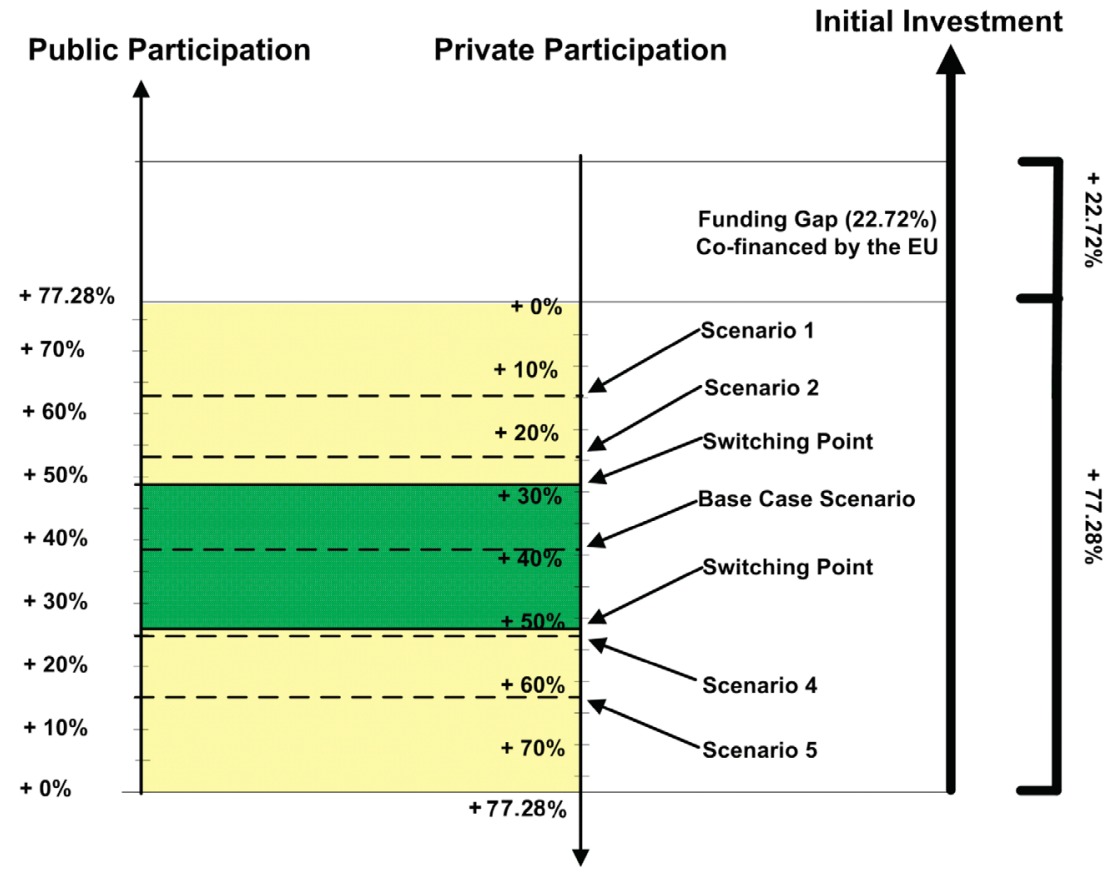

Figure 4: Alternative funding scenarios of the public and private partners. 
sector ( $12.74 \%$ by national or regional fund and $12.74 \%$ by local public capital). These values present the upper and lower boundaries of the funding ratios that the public and private participants should contribute in the initial investment, so as the project analysts can go further in the risk assessment of the CBA, by choosing funding ratios between these boundaries.

\section{DISCUSSION AND CONCLUSIONS}

This research examines the assessment and initial funding estimation process implemented by the project examiners during the feasibility stage of wastewater treatment projects. The specific study follows the option analysis, in which the project's alternative scenarios have already been examined and the optimum option is selected. A novel algorithmic-type procedure is introduced, which includes the process for the examination of the project's procurement option with PPPs and specifically the implementation of BOT contracts. The new process applies in cases where both the public and private sectors participate in the funding of the initial investment. The process is divided in six basic steps, as follows:

1. Initially, it includes the collection of the appropriate data.

2. In the second step, the quantitative VfM assessment process is used, in order to demonstrate that the PPP procurement option includes enough VfM.

3. The new approach takes into consideration that the project will be implemented in an EU's member state, so the CBA methodology is used in the third step, for the calculation of the funding gap rate and the estimation of the co-financing rate by the EU.

4. The financial as well as the economic analyses of a base case scenario are examined in the fourth step, where the remaining funding of the initial investment is covered equally by the public and the private sector.

5. In the fifth step, alternative funding ratios of the participants are examined and the partners' financial indicators are calculated in each scenario.

6. In the sixth step of the proposed process, two switching points are estimated, where all the financial viable funding schemes rest inside. Particularly, the switching points are calculated with the trial and error method, as follows:

- The first switching point results when the financial NPV of the public sector equals zero (i.e. the public sector's IRR equals the discount rate) and the relative NPV of the private sector is positive (i.e. the private sector's IRR is higher than the discount rate).

- The second switching point results when the financial NPV of the public sector is positive (i.e. the public sector's IRR is higher than the discount rate) and the relative NPV of the private sector equals zero (i.e. the private sector's IRR equals the discount rate).

It is mentioned that these switching points define the upper and lower boundaries for the winwin scenarios, which is crucial in all types of cooperative agreements [53]. Particularly, these boundaries include all the appropriate values of the funding ratios that the public and the private sectors should contribute in the initial investment. The new approach is used in an illustrative case study, where the implementation of a WT project through BOT contract is examined. The proposed process can be a useful tool to the project analysts during the WT project's feasibility stage, as it helps them to estimate the optimum funding scenario and to submit the appropriate proposal to decision makers, for the public and private sectors' funding ratios in the project's initial investment. 


\section{ACKNOWLEDGEMENTS}

The authors would like to thank the anonymous reviewers for their helpful comments and suggestions.

\section{REFERENCES}

[1] Abdulaal, W.A., Public-private partnership in regenerating unplanned settlements in Jeddah. International Journal of Sustainable Development \& Planning, 6(2), pp. 181-194, 2011.

[2] Jones, R. \& Noble, G., Managing the implementation of public-private partnerships. Public Money and Management, 28(2), pp. 109-114, 2008. doi: http://dx.doi.org/10.1111/j.14679302.2008.00629.x

[3] Reeves, E., Public Private Partnerships in the Irish Roads Sector: an Economic Analysis. Research in Transportation Economics, 15(1), pp. 107-120, 2005. doi: http://dx.doi. org/10.1016/S0739-8859(05)15009-4

[4] Grimsey, D. \& Lewis, M.K., Evaluating the risks of public private partnerships for infrastructure projects. International Journal of Project Management, 20(2), pp. 107-118, 2002. doi: http://dx.doi.org/10.1016/S0263-7863(00)00040-5

[5] Bovaird, T., Public-private partnerships: from contested concepts to prevalent practice. International Review of Administrative Sciences, 70(2), pp. 199-215, 2004. doi: http://dx.doi. org/10.1177/0020852304044250

[6] Zitron, J., Public-private partnership projects: Towards a model of contractor bidding decision-making. Journal of Purchasing \& Supply Management, 12(2), pp. 53-62, 2006. doi: http://dx.doi.org/10.1016/j.pursup.2006.04.002

[7] Maskin, E. \& Tirole J., Public-private partnerships and government spending limits. International Journal of Industrial Organization, 26(2), pp. 412-420, 2008. doi: http://dx.doi. org/10.1016/j.ijindorg.2007.05.004

[8] Ruuska, I. \& Teigland R., Ensuring project success through collective competence and creative conflict in public-private partnerships - A case study of Bygga Villa, a Swedish triple helix e-government initiative, International Journal of Project Management. 27(4), pp. 323-334, 2009. doi: http://dx.doi.org/10.1016/j.ijproman.2008.02.007

[9] Sotirchos, A., Karmperis, A.C., Aravossis, K. \& Tatsiopoulos, I., Financial sustainability of the waste treatment projects that follow PPP contracts in Greece: a formula for the calculation of the profit rate. Ecosystems and Sustainable Development VIII, WIT Transactions on Ecology and the Environment, 144, eds. Y. Villacampa \& C.A. Brebbia, WIT Press: Southampton, pp. 285-299, 2011.

[10] Grimsey, D. \& Lewis, M.K., Public Private Partnerships, the Worldwide Revolution in Infrastructure Provision and Project Finance (Chapter 1). The nature of partnerships, Edward Elgar: Cheltenham, pp. 5-9, 2007.

[11] Yescombe, E.R., Public-Private Partnerships: Principles of Policy and Finance (Chapter 2). PPPs-For and Against, Published by Elsevier Ltd: Oxford, pp. 15-28, 2007.

[12] Smith, N.J., Engineering Project Management, Blackwell Science Ltd: Oxford, pp. 321-323, 2002.

[13] World Bank Group, PPP in Developing Countries, 2007 data results from the PPI Project Database, The World Bank Group, Public Private Infrastructure Advisory Facility, pp. 13-19, http://ppi.worldbank.org/

[14] Federal Highway Administration, Synthesis of public private partnership projects for roads, bridges and tunnels from around the world 1985-2004, U.S. Department of Transportation, Washington, D.C., pp. 9-10, 2005. 
[15] Panggabean, A.T.P., Expanding Access to Basic Services in Asia and the Pacific Region: Public-Private Partnerships for Poverty Reduction, Asian and Development Bank, ERD Working Paper, No 87, pp. 1, 7, 14, 2006.

[16] Chiu, Wai-ip, How to Launch a Successful BOT Project, Edmond University of Hong - Kong, Thesis submitted, pp. 34, 1998.

[17] Asian Development Bank, Technical Assistance for Public Private Community Partnerships in Urban Services for the poor, A. 2, pp. 1-2, 2000.

[18] Zhang, X-q. \& Kumaraswamy, M.M., Hong Kong experience in managing BOT projects, Journal of Construction Engineering and Management. 127(2), pp. 154-162, 2001. doi: http:// dx.doi.org/10.1061/(ASCE)0733-9364(2001)127:2(154)

[19] Haarmayer, D. \& Mody, A., Financing Water and Sanitation Projects - The Unique Risks, The World Bank Group, Finance, Private Sector and Infrastructure Network, 151, pp. 1-4, 1998.

[20] European Commission, Guidelines for Successful Public - Private Partnerships, Directorate General Policy, pp. 14, 2003.

[21] European Commission, Green Book on Public Private Partnerships, Directorate - General Policy, COM 327, final, 2004.

[22] European Commission, Communication from the Commission to the European Parliament, the Council, the European Economic and Social Committee and the Committee of the Regions on PPP's and Community Law on Public Procurement and Concessions, Brussels, 569, par. 2.3.1, 2005.

[23] European Parliament, PPP's National Experiences in the European Union, Union's Internal Policies, Direct. A, Economic and Scientific Policy, 2006.

[24] United Nations, Guidebook on Promoting Good Governance in Public Private Partnerships, Economic Commission for Europe, pp. 68-69, 2008.

[25] Ye, S. \& Tiong, R.L.K., NPV-at-risk method in infrastructure project investment evaluation. Journal of Construction Engineering and Management, 126(3), pp. 227-233, 2000. doi: http:// dx.doi.org/10.1061/(ASCE)0733-9364(2000)126:3(227)

[26] HM Treasury, How to appoint and work with a preferred bidder, Technical Note No. 4, Treasury Taskforce, Private Finance, HMSO, London, 1999.

[27] Office of Government Commerce, Green public private partnerships, Norwich, pp. 4-5, 2002.

[28] Grimsey, D. \& Lewis M.K., Are Public Private Partnerships value for money? Evaluating alternative approaches and comparing academic and practitioner views, Accounting Forum. 29(4), pp. 345-378, 2005. doi: http://dx.doi.org/10.1016/j.accfor.2005.01.001

[29] HM Treasury Taskforce, How to manage the delivery of long term PFI contracts, Technical note No.6-London, 2003.

[30] HM Treasury, Value for money assessment guidance, London, 2004.

[31] Partnerships Victoria, Partnerships Victoria - Public sector comparator, Department of Treasury and Finance, Victoria, Australia, 2003.

[32] Spackman, M., Public-private partnerships: lessons from the British approach. Economic Systems, 26(3), pp. 283-301, 2002. doi: http://dx.doi.org/10.1016/S0939-3625(02)00048-1

[33] HM Treasury, http://www.hm-treasury.gov.uk/d/pfi_signed_projects_list.xls

[34] HM Treasury, PPP's, the Government's Approach, pp. 10, London, 2000.

[35] Department for Transport, Green Public Private Partnership, UK, p. 4, 2002.

[36] HM Treasury, Value for Money Assessment Guidance, London, 2006.

[37] HM Treasury, PFI Value for Money Quantitative Assessment, Evaluation Spreadsheet, http:// www.hm-treasury.gov.uk/d/vfm_qe_spreadsheet0307.xls 
[38] Zhang, X., Critical Success Factors for PPPs in Infrastructure Development. Journal of Construction Engineering \& Management, 131(1), pp. 3-14, 2005. doi: http://dx.doi.org/10.1061/ (ASCE)0733-9364(2005)131:1(3)

[39] Van Ham, H.\& Koppenjan, J., Building PPPs: Assessing and managing risks in port development, Public Management Review. 4(1), pp. 593-616, 2002.

[40] European Commission, Resource Book on PPP Case Studies, Directorate - General Regional Policy, pp. 9, 2004.

[41] European Commission, Guide to Cost-Benefit Analysis of Investment Projects, pp. 13-15, 2008.

[42] European Union Official Journal, Council Regulation (EC) No 1083/2006, of 11 July, 2006: Chapter II, Section 2, Article 39-40, 2006.

[43] Karmperis, A.C., Sotirchos, A., Aravossis, K. \& Tatsiopoulos, I., Funding evaluation model for the implementation of wastewater treatment projects through Public Private Partnerships. Environmental Economics and Investment Assessment III, WIT Transactions on Ecology and the Environment, 131, eds. K. Aravossis \& C.A. Brebbia, WIT Press: Southampton, pp. $147-160,2010$

[44] Karmperis, A.C., Sotirchos, A., Aravossis, K. \& Tatsiopoulos, I. Waste management project's alternatives: A risk-based multi-criteria assessment (RBMCA) approach. Waste Management, 32(1), pp. 193-211, 2012.

[45] United Nations, Guidelines on Municipal Wastewater Management, UN Environmental Programme, pp. 48-51, 2004.

[46] Organisation for Economic Cooperation \& Development, Handbook for Appraisal of Environmental Projects Financed from Public Funds, Environmental Finance, pp. 64-66, 2007.

[47] Asian Development Bank, Guidelines for the Economic Analysis of a Project, Economics and Development Resource Centre, pp. 167, 1997.

[48] Aravossis, K. \& Karydis, V., Combination of monetary valuation techniques and application to environmental impact receptors, Fresenius Environmental Bulletin, 13(3b), pp. 283-288, 2004.

[49] Latinopoulos, D., Valuing the services of coastal ecosystems: A meta-analysis of contingent valuation studies, International Journal of Sustainable Development \& Planning, 5(1), pp. 13-30, 2010. doi: http://dx.doi.org/10.2495/SDP-V5-N1-13-30

[50] Pearce, D., Atkinson, G. \& Mourato, S., Cost-Benefit Analysis and the Environment: Recent Developments, OECD publishing, pp. 253-267, 2006.

[51] HM Treasury, The Green Book: Appraisal and Evaluation in Central Government, London, Annex 2: Valuing non-market impacts, pp. 57-67, 2004.

[52] Day, B.H., The theory of hedonic markets: obtaining welfare measures for changes in environmental quality using hedonic market data, Research report, Centre for Social and Economic Research on the Global Environment (CSERGE) Publications, London, 2001.

[53] Karmperis, A.C., Sotirchos, A., Aravossis, K. \& Tatsiopoulos, I.A. cooperative game theory approach for the equal profit and risk sharing, Proc. of the 2nd European Conference of Systems (ECS 11), Puerto De La Cruz, Tenerife, Spain, December 10-12, 2011. 